\title{
Sentencing of Minor Offences in Indonesia: Policy, Practice and Reform
}

\author{
Christina Maya Indah Susilowati
}

Satya Wacana Christian University, Salatiga, Indonesia

\begin{abstract}
This paper seeks to evaluate minor offenses in the Criminal Code in Indonesia. So far, the value limit for determining minor offenses in Indonesia is increasingly irrelevant to the value of the currency due to inflation. It will cause a gap in criminal law in dealing with changes. As the result, police will do unfair and non-humanistic law implementation. The objective of this study is to identify the importance of revising the lower limit of minor offenses in the Criminal Code in Indonesia. The study used a socio-legal method on the contextualization of Indonesian Criminal Codes related to the categorization of minor offense regulation in Government Regulation No. 2 of 2012 and in Penal Code, by utilizing a humanitarian perspective in law enforcement, especially by police who still charge some minor offenses with 5 years imprisonment. The results confirmed that some changes have been made related to this matter as Indonesian Supreme Court has made some regulation, such as No. 2 of 2012 on adjustment in minor offense law. This means that all criminals doing minor offense cannot be hold as prisoners in the investigation or prosecution process. The main contribution of this study is to construct a perspective of legal and regulatory issues to emphasize a fair of justice in dealing with minor offenses with a model of humanistic law enforcement. The result is expected to practically contribute and recommend the importance of constructing fairness of justice principle in law enforcement in particular and of revising minor offence sentencing in general.
\end{abstract}

Keywords: Justice, minor offense, law enforcement, humanistic orientation, Indonesia.

\section{INTRODUCTION}

The regulation about minor offense is arranged in Indonesian Penal Codes originated from Wetboek van Strafrecht voor Nederlandsch Indie (WvSvNI). According to the Criminal Code, categorization in the minor offences is considered to be a violation of the rights of justice of people related to their wealth. However, the value limit for determining minor offenses in Indonesia is increasingly irrelevant to the value of the currency, insofar, due to inflation which is not taken into account as the basis for calculating minor offenses. The categorization of value loss in minor theft for example, is ranged under IDR 250 ( $1 \$$ equals to IDR 14,000). The Government Regulation No. 16 of 1960. The regulation about minor cases are also written in Article 205 of Penal Code which states that the cases investigated in minor case investigation are the cases possibly sentenced with the maximum 3 months imprisonment or the maximum IDR 7,500 fine. The articles that consider the loss of the materials value below IDR 250 as a conduct of crime is now inappropriate with the social-economical changes in the society.

The categorization of a minor offense is based on value loss and the possibility of a sentence. It affects the process of trial, which will lead to a quick investigation. To answer the juridical matter about the

*Address correspondence to this author at the Satya Wacana Christian University, Salatiga, JI. Diponegoro 52-60 Salatiga, Central Java, 50711, Indonesia; Tel: 0298-321212 ext. 245;

E-mail: christina.maya.fhuksw@gmail.com categorization of minor cases (Mustafa et al., 2020; Nasir et al., 2014), The Supreme Court of Indonesia produced Government regulations/regulation No. 2 of 2012. This regulation stated that all articles about minor crimes such minor theft, minor corruption, minor drug abuse), the fine of IDR 250 becomes IDR $2.5 \mathrm{M}$. In that case, the minimum fine for minor cases in Indonesia is IDR $2.5 \mathrm{M}$. The problem is, this Supreme Court Regulation does not apply to other law enforcements such as police and attorneys. To solve these problems, the related departments produced a Memorandum of Understanding. The MoU was made together by the Head of Indonesian Supreme Court, the Minister of Law and Human Rights, the Attorney General and the Head Indonesian Police. It regulates the application and the adjustment of minor offense categorization, related to the fines, the quick investigations, and the application of fair and restorative justice.

The implementation of Government Regulation No. 2 of 2012 is not as easy as it seems. The fine limit for minor case crimes is still below IDR 250. The order of justice then leads to a rigid, juridical and prescriptive behaviour. This behaviour then will cause a problem when are against with the value of justice in public. Formal justice will be seen differently from the substantial justice. The substantial justice is considered to be more trusted, dignified and true. Based on this description, this paper seeks to evaluate minor offenses in the Criminal Code in Indonesia. The objective of this study is to identify the importance of revising the lower limit of minor offenses in the Criminal Code in Indonesia. 


\section{LITERATURE REVIEW}

Hart et al. (2012) mention two conditions needed for the existence of law. First, there should be an acknowledgement that there is a law force assigned to create, change, apply, enforce and evaluate the primary law. This should be supported by the secondary law that binds and is accepted by the law enforcement forces. Secondly, every citizen should obey the primary law to make them have a sense of law consciousness. Condition number two stated by Hart \& Green (2012), is theoretically relevant to the culture of law mentioned by Friedman (1975). Culture of law is understood as a social support towards law. It refers to the society's habits, point of view, attitude, and way of thinking that will determine whether they obey or disobey the law (Khozim, 2009). The suitability between the Criminal Codes and the society where the law exists becomes a main requirement in undergoing the policy (Bahiej, 2005). The verdict/sentence given should cover society protection. Public, victim and the criminal interests should be all considered. This step reflects Criminal Law politics. That is why the verdict should have some characteristics like: humanity (prioritize dignity), educative (criminals are responsible for the crimes they do, they take this as a learning point to prevent them from doing further crimes), principle of fairness (the verdicts apply a sense of fairness towards the victim, the criminal and the public). Criminal policy always comes hand in hand with social policy. And social policy consists of social welfare and social defence policies. Criminal politics itself has two tools, penal law and non-penal law. This is why every judicative and applicative policy in concreto law enforcement has to achieve the goals of social policy of social welfare and social security. Marc Ancel (1998) stated that society requires social order, meaning that it needs to provide a set of regulations that meet their needs. Hence, Criminal Codes plays an important role in the society.

Criminal policy is a system established for crime prevention. The system should involve other subsystems consist of: police, attorneys, court, and penitentiary (Susilowati, 2019; Gulo et al., 2020). They should work together in an integrated justice system (Bolifaar et al., 2019). The aims of sentencing in Indonesian Criminal Code are to preventing crime from happening, handling the cases fairly so that it gives satisfaction for the enforcement of justice, and preventing the criminal actors from repeating their actions. The existing law's expressive aspect will be more dominant compared to repressive and autonomous justice, but the advantage is substantive justice will play an important role (Prasetyo \& Barkatullah, 2007). Hence, the paradigm of positivism (Ritzer \& Goodman, 2008) owns a contradictory sense of justice (Agger, 2003). Habermas (1996) states that the tension between normative approaches, which are constantly in danger of losing contact with social reality, continued unlike the facticity of law enforcement, this social facticity is no longer internally related to the legitimacy claimed for the legal order. Law order is having some distortions now. Law might undergo alienation due to public needs. This is called an arrogance of law coming from paradigm of positivism or legalism. Theoretical paradigm of positivism and legalism sees law as a separated characteristic that they call closed logical system. Legal positivism as the role model in law gives no considerations to dialogic and empathic approaches (Tyesta et al., 2020).

Ideally, law owns three ground foundations: justice, benefit and certainty (Leawoods, 2000). Justice obliges and requires every case being considered on its own term (ius suum cuique tribuere) (Guarino, 2010). Otherwise, meuwissen prefers freedom as the basic and the essence of a law. Freedom does not mean "I do as I wish". It refers that freedom is a means of bridging legal guarantee, justice, equality of rights, etc. (Friedrich, 2004). Criminal Codes has a characteristic of ultimum remedium (Firdaus \& Leviza, 2020). There should be some limitation here. It means that if the other aspects of the law are not adequate to define the norms acknowledged by the law, then the Criminal Codes are applicable. The threat of a sentence should stay ultimum remedium. This kind of system is a representation of an opinion that: "the police should be powerful but not oppressive; they should be efficient but not officious; they should form an impartial force in the politics; and yet subject to a degree of control by persons who are not required to be impartial and who are themselves liable to police supervision" (Skolnick, 2011). Related to the police attitude in the perspective of law enforcement and order, Indarti (2020) explains that a system of legal justice based upon the assumption of punishment has extorted tremendously negative effects on the professionalization of police service. In this case, law enforcement needs improvement (rechts verfijning).

\section{METHOD}

This study uses the socio-legal method. The sociology of law perspective wants to see and understand the legal reality from the perspective of 
social sciences, especially sociology or in other terms of social science about law. The study of socio-legal approach is a study that is subject to legal phenomena, by using social science and sociological theories (Soekanto, 2006). It analytically analyzes the reciprocal relationship between law and society. Sociology of law empirically examines the interrelationship between law and social phenomena (Sholahudin, 2017). In summary, the sociolegal approach examines law using the approach of legal science and social sciences.

In this study, a socio-legal method is identified in two ways: a textual study about Indonesian Criminal Codes and the humanistic contextualization of sentencing minor offences. The textual study is especially related to the categorization of minor offense regulation in Government Regulation No. 2 of 2012 and in Penal Code, while the regulatory contextualization is critically analyzed to find the meaning and its implication to the law enforcement. The expected results of the study are the representation of linkage between social reality context within which the law of minor offense exists, or an interface of a social context within which law exists (Budianto, 2020). More theoretically, as the result, the investigation of law by using socio-legal approach will reveal truth about law (Sidharta, 2000). Another consideration is that sociolegal method did not examine law only in its normativedogmatic nature (Rahardjo, 2009; Wiratraman, 2019).

Moreover, the object of the study of the sentencing of minor offences is the police as law enforcement agency and the law regulator in the minor offences. The police are seen as a gateway to prosecution and trial. Government Regulation No. 2 of 2012 plays an important role in regulating minor offenses and paving the way for a wider revision of the Criminal Code to develop humanistic police. This is to create a "justice friendly police" when they have to deal with the public. The steps conducted by the police in dealing with minor cases, are based on Penal Code detailed in Indonesian Criminal Law Act. As a means of humanistic orientation, the socio-legal approach in this study examines how Indonesian police should handle the minor offense as it is going to be useful to formulate how or in what condition this specific law paradigm appears to the surface. This specific condition will give dominant characteristic to the law order.

\section{RESULTS}

Criminal policy in Indonesia adheres to the categorization of minor offense conducts. The problem is, the policy that is not yet assertive and responsive to social changes. From the point of view of Legal Institution, The Indonesian Supreme Court has authority in (a) cassation trial, (b) reviewing regulations functioning less than law, (c) giving advice to other government bodies, (d) monitoring other justice/court bodies with less authority, (e) other administrative and monitoring authorities. This authority will enable the Supreme Court to deliver legal letters and regulations to make other legal institutions with less authority to run smoothly. This is legally regulated in the Indonesian Constitution in Article $24 \mathrm{~A}$, paragraph (1), due to the law policy adhered by The Criminal Code (Lumbuun, 2011). On February 27th 2012, Indonesian Supreme Court legally announced Government Regulation No. 2 of 2012. This Government regulations are about the adjustment (from Penal Code) of fine limits in minor offense conducts. It brings some changes, such as the person who conducts a minor offense that causes less than IDR $2.5 \mathrm{M}$ value loss, cannot be hold prisoner. This case refers to less serious. The categorization of minor offense relates to the value loss. The loss should be less than IDR $2.5 \mathrm{M}$.

Criminal Codes enforcement is considered ineffective if its application does not fit society values. The application of minor offense law using the commonly used regulation will cause an abundance of unfinished cases. Police Institution is not merely assigned to attend this kind of cases. In some cases, the criminals experience disproportionate inconvenience compared to the crimes have done. The police and other law enforcement are prefer to apply a rigid and formal old fashioned and out of date Criminal Codes. The Indonesian police are not yet prepared for an assertive progressive law system. Operational procedure in law is taken as a technical matter only. There is some consideration in the establishment of government Regulation No. 2 of 2012: the absence of law. Since 1960, rupiah value has been decreasing ten thousand times compared to gold value. This regulation is not meant to change the content of the Penal Code. The Supreme Court only adjusted rupiah value to its nowadays (appropriate) condition. From the point a view of justice, it will be easier for the law force such as judges to produce fair justice for the cases on trial.

In fact, Government Regulation No. 2 of 2012 is not yet applied. Instead of being formulated as a response of fair justice to the appropriate regulation in Penal Code, what happens in the field is the opposite. Hence, many obstacles were found. The steps being taken by the law force are usually as follows. First, referring to 
Penal Code, they do not apply the categorization of fine/sentence under IDR $2.5 \mathrm{M}$ for minor offense law. Second, the criminals committing minor offense are still held as prisoners. The police have some reasons for doing this. The regulation in penal Code is still effective and they are bound to obey the regulation made by The Supreme Court. Third, the investigation done for the criminals committing minor offense should be quick with a single judge. On the other hand, they undergo investigation.

Government Regulation No. 2 of 2012 is not in accordance with Law Number 12 of 2011 that rules the law-making. Government regulations do not have authority (is not mentioned) in the hierarchy of law making, as stated in article 7. The Police or Attorney Department are not obliged to follow the regulation. They can carry out their responsibilities under the Criminal Code and civil law.

In this context, the criminals committing minor offense are sentenced with lengthy imprisonment. There is a need to find an alternative for imprisonment. Legalistic tendencies approach taken by Police in dealing with minor violation conducts will violate public justice. These cases are brought to trials because in Penal Code they are considered as minor offenses conducts that cause a maximum IDR 250 value loss. There will be no more crimes that can be categorized as minor offense conducts if this kind of calculation is used. This can be done in dealing with a community that has been changing, including their changes in valuing the wealth (Kurniawan, 2020). Minor offense law with a fine less than IDR 250 is not in accordance/ appropriate with the current Indonesian culture of law. On the other hand, a fine less than IDR $2.5 \mathrm{M}$ is considered as expensive and violates public justice. In a responsive justice point of view, criticism is given to minor offense law/policy and its application in Indonesia.

\section{DISCUSSION}

Restorative justice is a step taken for penal mediation in dealing with minor offense conducts. The aspect of police discretion should be prioritized in handling misdemeanor. It should also suit the public justice, such as in some cases of a misdemeanor (Koss, 2010; Bergseth \& Bouffard, 2013). Police awareness should be enhanced to find the true value of public justice in dealing with minor offense conducts by using the restorative justice approach (Marder, 2020). Inflexibility application of less serious cases by police has to be eliminated by implementing restorative justice to enforce law order. The advantage of undertaking penal mediation in minor offense cases, is worth trying. This will minimize the stiffness of Criminal Codes in Indonesian law when it concerns minor offences. The consequences of Indonesian old fashioned minor offense law are as follows. First, the police will have a pile of less serious cases to attend. Government Regulation No. 2 of 2012 brings paradigmatic problem in the society, either in its formulation or implementation.

Second, it should be understood that Criminal Codes based on imprisonment are not the best solution for minor offense conducts, related to punishment in less serious cases Third, the categorization of crimes in minor offense stays close with the level of violation in society's order. It shows the limit of public tolerance towards certain crime. It needs to pay more attention to more reasonable Criminal Codes related to minor offense. Instead of imprisonment, an effective and humanist punishment can be applied such as social work or fine. Other data can be viewed in Polish Criminal Code stated that if the offence is threatened only by penalty of deprivation of liberty, the lower limit of sanction is not higher than 3 months and the penalty imposed would not exceed 6 months imprisonment, and the court recognized that the sentencing to such a penalty would not serve a purpose, a judge may put the penalty of limitation of liberty or a fine (Grajewski \& Lammich, 1981). As a comparison, an example is taken from Bulgarian Criminal Code, where Article 54 (1) that the court shall determine punishments within the limits provided by law for the crime committed (CJAD, 2010).

The categorization in crime conducts for minor offense uses a main economic principle. This principle is used to analyse the efficiency. A regulation is considered as efficient, if in defining and enhancing law for a misconduct, they show balance. This balance means the price and the benefit are equals. Second, the police repressive attitude towards minor offense conducts will cause unsatisfactory complaints. In the constellation of law positivism, the law serves itself. It emphasizes only in its formal aspect instead of its essence of justice and humanity. The rigidity, dogmatism, and detachment of law from its moral, will cause a degradation of law. The categorization of minimum fine for value loss should be in accordance with the society's money value. The categorization of value loss must consider the sociological condition where the law exists. The misjudgement in 
criminalizing error will cause a discrepancy between government law and the law acknowledged by the society. The main point is that the Criminal Codes should go harmoniously with the values believed by the society. Defining a crime must include these important aspects: the level of social danger by the act and perpetrator, the motives behind the crime, and the context in which the crime takes place. These aspects will judge whether the case is less or more serious. It is guided by the provisions of the general part of this Code and taking into consideration the following: the degree of social danger, the motives for perpetration of the crime, and other attenuating aggravating circumstances.

\section{CONCLUSION}

The results of this study specifically indicate the need for an evaluation of the law enforcement of misdemeanour in the Indonesian Penal Code by using a socio-economic perspective based on a humanitarian approach through restorative justice. Specifically, the findings show the lack of responsiveness of law enforcement agencies in dealing with social changes, and less attention to the aspect of expired material limitations stipulated in the Indonesian Criminal Code in dealing with minor crimes that are currently occurring. The results confirmed that some reforms have been made related to this fine as the Indonesian Supreme Court has made some regulation, such as No. 2 of 2012 on adjustment in minor offense law. This means that all criminals doing minor offense cannot be hold prisoners in the investigation or prosecution process. In dealing with minor offense conduct, the humanistic orientation approach should be put forward to create harmony and propriety of law. In this regard, a community resolution can be enhanced in handling misdemeanor with lesser value loss. Restorative justice approaches are also applicable in community resolution. Discretion has some possibility to develop in the approach of order. This might come from the police point of view: minimizing the significance and reason for failure in reporting the crimes, the discretion of the police for not doing the arrest, the discretion of the prosecutors not to prosecute. This study also identifies the importance of revising the lower limit of minor offenses in the Criminal Code in Indonesia and the contextualization of Indonesian Criminal Codes related to the categorization of minor offense regulation in Government Regulation No. 2 of 2012 and in Penal Code. It puts forward for consideration of utilizing a humanitarian perspective in law enforcement, especially by police who still charge some minor offense with 5 years imprisonment in some cases of misdemeanour.

Hence, as the practical and theoretical implications, the results about minor offense law practice in Indonesia recommend some reformations in reviewing critically the law system to define the categorization of minor offense laws. The efficiency in Criminal Codes is obtained when the procedure taken are well supported by the society. In investigating and judging a misconduct as a crime, there should be some criteria which states that the misconduct has violated other's right and caused anxiety. It will prove to the public that a minor offense conduct does not need a repressive action. The main contribution of the study is to construct a perspective of legal and regulatory issues to emphasize a fair practice of justice in dealing with minor offense with a model of humanistic law enforcement. The result is expected to practically contribute and recommend the importance of constructing fairness of justice principle in law enforcement in particular and of revising minor offence sentencing in general. The regulation specifying minor offences should be seen as a response to facilitate the social needs and aspiration. This should imply that, first, the law/regulation is functional, pragmatic, goaloriented and rational. Second, the goal in setting standards will serve to manage administrative flexibility and minimize the risk of the bad institutional reputation of law enforcement bodies.

\section{REFERENCES}

Agger, B. (2003). Critical Social Theory: Criticism, Its Application and Implications. Kreasi Wacana.

Ancel, M. (1998). Social defence: A modern approach to criminal problems (Vol. 199). Psychology Press.

Bahiej, A. (2005). History and Problems of Material Criminal Law in Indonesia. Jurnal Sosio-Religia, 4(4).

Bergseth, K. J., \& Bouffard, J. A. (2013). Examining the effectiveness of a restorative justice program for various types of juvenile offenders. International journal of offender therapy and comparative criminology, 57(9), 1054-1075. https://doi.org/10.1177/0306624X12453551

Bolifaar, A.H., Jaya, N.S.P., Pujiyono, \& Arif, F. (2019). Authority of Indonesian attorney in handling the corruption crimes: A perspective of integrated criminal justice system. Journal of Legal, Ethical and Regulatory Issues 22(5), 1-8

Budianto, A. (2020). Legal Research Methodology Reposition in Research on Social Science. International Journal of Criminology and Sociology, 9. https://doi.org/10.6000/1929-4409.2020.09.154

Cooperation and Judicial Assistance Database/CJAD. (2010). Republic of Bulgaria Criminal Code 1968. University of Nottingham. Retrieved from https://cjad.nottingham.ac.uk/en/legislation/172/keyword/616/

Firdaus, A., \& Leviza, J. (2020, March). Environmental Criminal Responsibility for Mining Corporation Through the Ultimum Remedium Principle. In International Conference on Law, 
Governance and Islamic Society (ICOLGIS 2019) (48-50). Atlantis Press.

https://doi.org/10.2991/assehr.k.200306.179

Friedman, L. M. (1975). The legal system: A social science perspective. Russell Sage Foundation.

Friedrich, C. J. (2004). Legal philosophy of historical perspective. Bandung: Nuansa Nusamedia.

Grajewski, J., \& Lammich, S. (1981). Criminal Policy in Poland in Light of the Criminal Code of 1969. Rev. Socialist L., 7, 407. https://doi.org/10.1163/187529881X00245

Guarino, A. (2010). Ius Suum Cuique Tribuere. Historical Background and Contemporary Implementation in Civil and Penal Law. Acta luridica Olomucensia, 5(1), 131-135.

Gulo, N., Jaya, N.S.P., \& Pujiyono. (2020). Managerial factors of education program performance in correctional institutions. International Journal of Scientific and Technology Research 9(4), 749-751.

Habermas, J. (1996). Between Facts and Norms. Cambridge: Polity. https://doi.org/10.7551/mitpress/1564.001.0001

Hart, H. L. A., Hart, H. L. A., \& Green, L. (2012). The concept of law. Oxford University Press. https://doi.org/10.1093/he/9780199644704.001.0001

Indarti, E. (2020). Strengthen Security and Public Order: Accountability Management in Improving the Quality of Law Enforcement. Academic Journal of Interdisciplinary Studies, 9(2), 82-82. https://doi.org/10.36941/ajis-2020-0025

Khozim, M. (2009). Theories of Learning. Bandung: Nusa Media.

Koss, M. P. (2010). Restorative justice for acquaintance rape and misdemeanor sex crimes. Restorative justice and violence against women, 218-238. https://doi.org/10.1093/acprof:oso/9780195335484.003.0010

Kurniawan, R.C. (2020). Scientific deliberation of strategic partnership in law enforcement with local communities. International Journal of Scientific and Technology Research 9(3), 514-518.

Leawoods, H. (2000). Gustav Radbruch: An extraordinary legal philosopher. Wash. UJL \& Pol'y, 2, 489.

Lumbuun, R. S. (2011). PERMA RI as a Form of Confusion Between the Practice of Division and Separation of Powers. Jakarta: Raja Grafindo Persada.

Marder, I. D. (2020). Institutionalising restorative justice in the police: key findings from a study of two English police forces. Contemporary Justice Review, 23(4), 500-526. https://doi.org/10.1080/10282580.2020.1755847
Mustafa, C., Malloch, M., \& Hamilton Smith, N. (2020). Judicial perspectives on the sentencing of minor drug offenders in Indonesia: discretionary practice and compassionate approaches. Crime, Law and Social Change, 74, 297-313. https://doi.org/10.1007/s10611-020-09896-0

Nasir, S., Rosenthal, D., \& Moore, T. (2014). "It's not easy but it's still possible to be an abstainer here": Non-Drug Use Among Young Men in a Slum Area in Makassar, Indonesia. International Journal of Criminology and Sociology, 3, 336347. https://doi.org/10.6000/1929-4409.2014.03.29

Prasetyo, T., \& Barkatullah, A. H. (2007). Legal science \& legal philosophy: the study of legal experts throughout the ages. Yogyakarta: Pustaka Pelajar.

Rahardjo, S. (2009). Penegakan Hukum: Suatu Tinjauan Sosiologis. Genta Publishing.

Ritzer, G., \& Goodman, D. J. (2008). Modern Theory of Sociology. Jakarta: Kencana

Sholahudin, U. (2017). Pendekatan sosiologi hukum dalam memahami konflik agraria. Dimensi-Journal of Sociology, 10(2).

Sidharta, B. A. (2000). Reflections on the Structure of Legal Studies: a study of the foundations of the philosophical and legal nature of Law as the Foundation for the Development of Indonesian National Law. Bandung: Universitas Padjajaran.

Skolnick, J. H. (2011). Justice without trial: Law enforcement in democratic society. Quid Pro Books.

Soekanto, S. (2006). Pengenalan Penelitian Hukum. Grafindo, Jakarta.

Susilowati, C. M. I. (2019). Establishing humanistic tendencies through restorative justice in the law enforcement context. Journal of Legal, Ethical and Regulatory Issues, 22(2), 1-6.

Tyesta, L.A.L.W., Saraswati, R., \& Arif, F. (2020). Implications of legal positivism of the promotion of children's rights on national law. Journal of Advanced Research in Law and Economics 11(2), 661-666. https://doi.org/10.14505/jarle.v11.2(48).36

Wiratraman, H. P. (2019). The Challenges of Teaching Comparative Law and Socio-Legal Studies at Indonesia's Law Schools. Asian Journal of Comparative Law, 14(S1), S229-S244. https://doi.org/10.1017/asjcl.2019.15

Received on 24-02-2021

Accepted on 30-03-2021

Published on 08-04-2021

https://doi.org/10.6000/1929-4409.2021.10.92

(C) 2021 Christina Maya Indah Susilowati; Licensee Lifescience Global.

This is an open access article licensed under the terms of the Creative Commons Attribution Non-Commercial License (http://creativecommons.org/licenses/by-nc/3.0/) which permits unrestricted, non-commercial use, distribution and reproduction in any medium, provided the work is properly cited. 